\title{
Correction to: The biological Maxwell's demons: exploring ideas about the information processing in biological systems
}

\author{
Eduardo Mizraji ${ }^{1}$ (D)
}

Published online: 21 September 2021

(c) The Author(s) 2021

\section{Correction to: Theory in Biosciences https://doi.org/10.1007/s12064-021-00354-6}

Authors would like to correct the error in their publication.

This last paragraph, previous to Appendix 1, begins with the expression "Maxwell's physical theory of demons ...". However, the correct version is "Physical theory of Maxwell's demons ...".

The original article has been corrected.

Open Access This article is licensed under a Creative Commons Attribution 4.0 International License, which permits use, sharing, adaptation, distribution and reproduction in any medium or format, as long as you give appropriate credit to the original author(s) and the source, provide a link to the Creative Commons licence, and indicate if changes were made. The images or other third party material in this article are included in the article's Creative Commons licence, unless indicated otherwise in a credit line to the material. If material is not included in the article's Creative Commons licence and your intended use is not permitted by statutory regulation or exceeds the permitted use, you will need to obtain permission directly from the copyright holder. To view a copy of this licence, visit http://creativecommons.org/licenses/by/4.0/.

Publisher's Note Springer Nature remains neutral with regard to jurisdictional claims in published maps and institutional affiliations.

The original article can be found online at https://doi.org/10.1007/ s12064-021-00354-6.

\section{Eduardo Mizraji}

emizraji@gmail.com; mizraj@fcien.edu.uy

1 Group of Cognitive Systems Modeling, Biophysics and Systems Biology Section, Facultad de Ciencias, Universidad de La República, Iguá 4225, 11400 Montevideo, Uruguay 